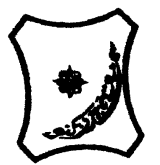

Bayero Journal of Pure and Applied Sciences, 11(1): 47 - 51

Received: December, 2017

Accepted: March, 2018

ISSN $2006-6996$

\title{
EVALUATION OF ANTIMICROBIAL ACTIVITY AND PHYTOCHEMICAL COMPOSITION OF SOME FRACTIONS OF METHANOL STEM BARK EXTRACT OF Diospyros mespiliformis
}

\author{
Abubakar, ${ }^{1}$ H. M.G., ${ }^{*}$ Usman, ${ }^{2}$ H. and $\mathrm{Karumi}_{,}{ }^{1}$ Y. \\ ${ }^{1}$ Department of Biochemistry, University of Maiduguri, P.M.B. 1069, Maiduguri, Nigeria \\ ${ }^{2}$ Department of Chemistry, University of Maiduguri, P.M.B. 1069, Maiduguri, Nigeria \\ *Corresponding author: usmanhamidu@unimaid.edu.ng, husman321@yahoo.com; +234 8028332246
}

\section{ABSTRACT}

The aim of this study was to determine the active phytochemical(s) most probably responsible for microbial inhibitions, following a bioassay guided protocol. Column chromatographic fractions (AG) obtained from n-Butanol partitioned portion of stem bark extract of Diospyros mespiliformis were analyzed for phytochemical composition. These were subjected to antimicrobial activity tests on clinical isolates of Staphylococcus aureus, Streptococcus pyogenes, Pseudomonas aeruginosa, Klebsiella pneumoniae and Candida albicans. Phytochemical screening conducted on the column fraction $E$ revealed the presence of tannins, free anthraquinones, cardiac glycosides, saponins, terpenoids, and flavonoids. The anti-microbial test results from fractions $A, B, F$ and $G$, obtained showed no inhibition against most of the micro-organisms tested, while fractions $C, D$ and $E$ showed significant $(P<0.05)$ activities with diameters of inhibition zone of inhibition ranging from $15.00 \pm 1.00 \mathrm{~mm}$ to $13.00 \pm 6.67 \mathrm{~mm}$ against Streptococcus pyogenes at all the concentrations tested (50, 12.5, $6.25 \mathrm{mg} / \mathrm{ml}$ equivalent to 3, 1.5 and $0.75 \mathrm{mg} /$ disc). The column fraction $E$ showed the highest inhibition zones with broader concentration dependent pattern with MIC at 12.5 $\mathrm{mg} / \mathrm{ml}$. The findings from this study showed the presence of bio-active components against Streptococcus pyogenes with relative higher potency in fraction $E$. Based on this findings, it can be surmised that Fraction $E$ with significant dose-dependent activity is expected to revealed a potent broad-spectrum antimicrobial agent and thus recommended for further purification stages towards compound(s) isolation of a novel antimicrobial agent.

Keywords: Antimicrobial, Diospyros mespiliformis, Phytochemical, Potency, Stem Bark

\section{INTRODUCTION}

Some pathogenic microorganisms are becoming resistant to most of the available antibiotics (Ochiai et al., 1959; Li and Frances, 2009). The resistance of Streptococcus to penicillin and other beta-lactams is increasing Worldwide (Liu et al., 2009). Staphylococcus aureus is one of the major resistant pathogens found on the mucus membrane and on the human skin (Li and Frances, 2009). Most strains are resistant to penicillin, methicillin, tetracycline and erythromycin. Pseudomonas is a highly prevalent opportunistic pathogen with low antibiotic susceptibility (Bodzogen et al., 2003).

Plants are used in the traditional medicine to treat various types of ailments (Adewumi, 2001). Many plant species are reported to posses antimicrobial activities (Abo et al., 1999; including the plant Diospyros mespiliformis (Maundu and Tengnas, 2005; Usman et al., 2013a). Diospyros mespiliformis is a deciduous tree found mostly in the Savanna of Africa (Adams, 1966). The tree flowers, in the rainy season, the female tree bears fruits in the dry season (Burkill, 1985). The plant Diospyros mespiliformis have been reported to be a useful source of antibiotic substances amongst the local populace (Simons et al., 2009). Furtherance to the earlier studies on the crude extract (Usman et al., 2013a; Abubakar et al., 2017) and more the use of varying degree of solvents extracting different group of phytocompounds, it is pertinent to solvent-partitioned the crude extract in order to reduce the complexity as well as the masking effect of some of the compounds (Usman et al., 2009a,b). It is therefore, hoped that the partially purified fractions obtained from the column chromatography of the $n$ butanol extract of the stem bark of this plant, if further purified and the active components isolated might be a useful source of novel antibiotics that would be used to treat some resistant pathogenic micro-organisms.

\section{MATERIALS AND METHODS}

\section{Sample collection}

The Diospyros mespiliformis plant was collected in Jimtilo Village, Kaga Local Government Area, Borno State, Nigeria. The sample was brought to the Department of Biological Sciences University of Maiduguri for identification by a Taxonomist; the voucher No. 13/CHM/002 was given and sample deposited in Research Laboratory, Department of Chemistry University of Maiduguri The sample was chopped into pieces and then dried completely under shade (between $38-40{ }^{\circ} \mathrm{C}$ ) and finally made into coarse powder using wooden mortar and pestle. 


\section{Test microorganisms}

Two Gram positive organisms: Staphylococcus aureus, Streptococcus pyogenes; two Gram negative organisms: Pseudomonas aeruginosa, Klebsiella pneumoniae and a fungal species, Candida albicans were used in the study. The micro-organisms were clinical isolates obtained from the Department of Veterinary Medicine, University of Maiduguri, Borno State.

\section{Extraction Procedure}

The stem bark of Diospyros mespiliformis was extracted with $80 \%$ methanol using the soxhlet extraction method, partitioned with solvents of graded polarities (chloroform, ethyl acetate, $n$-Butanol and residual aqueous portion) (Usman et al., 2013b). Forty grams $(40 \mathrm{~g})$ of the $n$-Butanol portion was loaded on to the column, containing silica gel of mesh size $60-120 \mathrm{G}$ and the different components were separated using the solvent system of chloroform/methanol in the ratio of 100:00 (400 ml), $80: 20(400 \mathrm{ml}), 60: 40(400 \mathrm{ml}), 50: 50(400 \mathrm{ml})$, 40:60 (400 ml), 20:80 (400 ml), and 00:100 (400 ml): were used as mobile phase of the column chromatography to obtain the series of fractions A-G respectively. Each fraction was dried completely in the oven at $37{ }^{\circ} \mathrm{C}$ in a weighed beaker and kept in the desiccator for further analysis.

\section{Phytochemical Tests}

The active fraction was screened phytochemically using conventional methods of phytochemical analyses (Sofowora, 1993; Evans, 2002; Vishnoi, 1979).

Fehling's test for free reducing sugar: About 0.5 $\mathrm{g}$ each portion was dissolved in distilled water and filtered. The filtrate was heated with $5 \mathrm{ml}$ of equal volumes of Fehling's solution A and B. Formation of a red precipitate of cuprous oxide was an indication of the presence of reducing sugars (Sofowora, 1993).

Fehling's test for Combined Reducing Sugars: About $0.5 \mathrm{~g}$ each portion was hydrolysed by boiling with $5 \mathrm{ml}$ of dilute hydrochloric acid and the resulting solution neutralised with sodium hydroxide solution. To this, few drops of Fehling's solution was added and then heated on a water bath for 2 minutes. Appearance of a reddish-brown precipitate of cuprous oxide indicates the presence of combined reducing sugars (Sofowora, 1993).

Test for Tannins: About $0.5 \mathrm{~g}$ each portion was stirred with about $10 \mathrm{ml}$ of distilled water and then filtered. Few drops of $1 \%$ ferric chloride solution were added to $2 \mathrm{ml}$ of the filtrate occurrence of a blueblack, green or blue-green precipitate indicates the presence of tannins (Evans, 2002).

Borntrager's Test: About $0.2 \mathrm{~g}$ of each portion to be tested was shaken with $10 \mathrm{ml}$ of benzene and then filtered. Five millilitres of the $10 \%$ ammonia solution was then added to the filtrate and thereafter the shaken. Appearance of a pink, red or violet colour in the ammoniacal (lower) phase was taken as the presence of free anthraquinones (Sofowora, 1993).

Test for terpenoids: A little of each portion was dissolved in ethanol. To it $1 \mathrm{ml}$ of acetic anhydride was added followed by the addition of conc. $\mathrm{H}_{2} \mathrm{SO}_{4}$. A change in colour from pink to violet showed the presence of terpenoids (Sofowora, 1993).

Test for Saponins: One gram of each portion was boiled with $5 \mathrm{ml}$ of distilled water, filtered. To the filtrate, about $3 \mathrm{ml}$ of distilled water was further added and shaken vigorously for about 5 minutes. Frothing which persisted on warming was taken as an evidence for the presence of saponins (Sofowora, 1993).

Shinoda's test for flavonoids: About $0.5 \mathrm{~g}$ of each portion was dissolved in ethanol, warmed and then filtered. Three pieces of magnesium chips was then added to the filtrate followed by few drops of conc. $\mathrm{HCl}$. A pink, orange, or red to purple colouration indicates the presence of flavonoids (Evans, 2002).

Ferric chloride test for flavonoids: About 0.5 of each portion was boiled with distilled water and then filtered. To $3 \mathrm{ml}$ of the filtrate, few drops of $10 \%$ ferric chloride solution were then added. A green-blue or violet colouration indicated the presence of a phenolic hydroxyl group (Evans, 2002).

\section{Antimicrobial Activity Test}

The n-Butanol column fractions ( $A$ - $G$ ) obtained were concentrated and air dried to constant weight and then subjected to antimicrobial susceptibility test in accordance to the disc diffusion technique as described by Kirby-Bauer et al. (1966); El-Mahmood, (2009). The extractives were made in three different concentrations of $50 \mathrm{mg} / \mathrm{ml}, 25 \mathrm{mg} / \mathrm{ml}$ and 12.5 $\mathrm{mg} / \mathrm{ml}$ by dissolving $0.50 \mathrm{~g}, 0.25 \mathrm{~g}$ and 0.125 of the column fractions in $10 \mathrm{ml}$ of $80 \%$ methanol solution each. Fifteen pieces of Whatmann filter paper No. 1 were submerged into $1 \mathrm{ml}$ of each of the extract concentrations to assume uniformity of absorption. The disc were left to dry completely. Each of the discs was considered to have absorbed $0.06 \mathrm{ml}$ equivalent to $3 \mathrm{mg} /$ disc at $50 \mathrm{mg} / \mathrm{ml}, 1.5 \mathrm{mg} / \mathrm{disc}$ at $25 \mathrm{mg} / \mathrm{ml}$ and $0.75 \mathrm{mg} /$ disc at $12.5 \mathrm{mg} / \mathrm{ml}$ as a constant working concentration. The sterile prepared plates were inoculated with the isolates and the impregnated discs were carefully placed on the already inoculated nutrient agar plate. The extracts were allowed to diffuse into the agar for an hour then the plates were incubated over night at $30^{\circ} \mathrm{C}$. Each extract was tested in triplicate. After 24 hours, the diameter of inhibition zones were observed, measured and recorded.

\section{RESULTS}

The results of the phytochemical screening of $n$ butanol column fraction $E$ of stem bark extract of Diospyros mespiliformis is as shown in Table 1; while Table 2 shows the antimicrobial susceptibility pattern of the n-butanol fractions of stem bark extract of Diospyros mespiliformis against some pathogenic microorganisms.. There was complete inhibition against the effect of fraction $A$ and $B$ at all concentration tested, though fractions $C$ and $D$ had broad-spectrum activity but no significant $(P>0.05)$ between the concentrations. Fractions $E$ and $F$ are sensitive to Gram negative and fungal species tested in a dose-dependent fashion. 
Table 1: Phytochemical constituents of the $n$-Butanol portion and column fraction $\mathrm{E}$ (most active) of the stem bark of Diospyros mespiliformis*

\begin{tabular}{|c|c|c|c|}
\hline S/No. & Constituents & n-Butanol Portion & $\begin{array}{l}\text { n-Butanol Colum } \\
\text { fraction 'E' }\end{array}$ \\
\hline \multirow[t]{3}{*}{1.} & Anthraquinones & & \\
\hline & a) Free & + & + \\
\hline & b) Combined & - & + \\
\hline \multirow[t]{3}{*}{2.} & Carbohydrates & & \\
\hline & a) Free reducing sugar & + & + \\
\hline & b) Combined reducing Sugar & + & + \\
\hline \multirow[t]{2}{*}{3.} & Cardiac glycosides & + & + \\
\hline & & + & + \\
\hline \multirow[t]{3}{*}{4.} & Flavonoids & + & + \\
\hline & & + & + \\
\hline & & + & + \\
\hline 5. & Saponins & + & + \\
\hline \multirow[t]{2}{*}{6.} & Tannins & + & + \\
\hline & & + & + \\
\hline 7. & Terpenoids & + & + \\
\hline
\end{tabular}

Key: $+=$ present; - = absent, $*$ NB: phytochemical components of the Crude and partitioned portion has been reported Abubakar et al. (2016; 2017).

Table 2: Antimicrobial activity of stem bark column fractions of Diospyros mespiliformis

\begin{tabular}{|c|c|c|c|c|c|c|c|}
\hline \multirow{2}{*}{$\begin{array}{l}\text { Column } \\
\text { fractions }\end{array}$} & \multirow[t]{2}{*}{ Rf values } & \multirow{2}{*}{$\begin{array}{l}\text { Conc. } \\
\mathrm{mg} / \mathrm{ml}\end{array}$} & \multicolumn{5}{|c|}{$\begin{array}{c}\text { Microorganisms/Diameter of Inhibition Zone }(\mathrm{mm}) \text { Mean } \pm \\
\text { SEM }\end{array}$} \\
\hline & & & $\mathbf{K I}$ & Ps & St & $\mathbf{S r}$ & Cn \\
\hline \multirow[t]{2}{*}{$A$} & 0.43 & 12.5 & $0.00 \pm 0.00$ & $0.00 \pm 0.00$ & $0.00 \pm 0.00$ & $0.00 \pm 0.00$ & $0.00 \pm 0.00$ \\
\hline & $C: M(7: 3)$ & 25.0 & $0.00 \pm 0.00$ & $0.00 \pm 0.00$ & $0.00 \pm 0.00$ & $0.00 \pm 0.00$ & $0.00 \pm 0.00$ \\
\hline \multirow[t]{2}{*}{ B } & 0.50 & 12.5 & $0.00 \pm 0.00$ & $0.00 \pm 0.00$ & $0.00 \pm 0.00$ & $0.00 \pm 0.00$ & $0.00 \pm 0.00$ \\
\hline & $C: M(6: 4)$ & 25.0 & $0.00 \pm 0.00$ & $0.00 \pm 0.00$ & $0.00 \pm 0.00$ & $0.00 \pm 0.00$ & $0.00 \pm 0.00$ \\
\hline \multirow[t]{3}{*}{ C } & 0.65 & 12.5 & $10.00 \pm 0.00$ & $0.00 \pm 0.00$ & $10.00 \pm 0.00$ & $12.00 \pm 1.00$ & $10.66 \pm 0.58$ \\
\hline & $C: M(4: 6)$ & 25.0 & $12.00 \pm 0.00$ & $0.00 \pm 0.00$ & $13.00 \pm 1.00$ & $15.00 \pm 1.00$ & $13.00 \pm 0.00$ \\
\hline & & 50.0 & $11.30 \pm 0.58$ & $0.00 \pm 0.00$ & $13.00 \pm 0.00$ & $14.33 \pm 0.58$ & $14.00 \pm 0.00$ \\
\hline \multirow[t]{3}{*}{$D$} & 0.70 & 12.5 & $10.00 \pm 0.00$ & $0.00 \pm 0.00$ & $10.33 \pm 0.58$ & $12.33 \pm 0.58$ & $10.66 \pm 0.58$ \\
\hline & $C: F: W$ & 25.0 & $10.33 \pm 0.58$ & $0.00 \pm 0.00$ & $12.33 \pm 0.58$ & $14.00 \pm 0.00$ & $12.66 \pm 0.58$ \\
\hline & $(10: 1: 1)$ & 50.0 & $14.00 \pm 1.00$ & $0.00 \pm 0.00$ & $13.00 \pm 0.00$ & $15.33 \pm 0.58$ & $14.66 \pm 0.58$ \\
\hline \multirow[t]{3}{*}{$E$} & 0.76 & 12.5 & $0.00 \pm 0.00$ & $0.00 \pm 0.00$ & $10.33 \pm 0.58$ & $10.33 \pm 0.58$ & $9.66 \pm 0.58$ \\
\hline & $C: F: W$ & 25.0 & $9.00 \pm 0.00$ & $0.00 \pm 0.00$ & $11.66 \pm 0.58$ & $13.66 \pm 0.58$ & $11.33 \pm 1.15$ \\
\hline & $(10: 1: 1)$ & 50.0 & $10.00 \pm 0.00$ & $0.00 \pm 0.00$ & $14.33 \pm 0.58$ & $15.33 \pm 0.58$ & $14.66 \pm 0.58$ \\
\hline \multirow[t]{2}{*}{$\mathrm{F}$} & 0.96 & 12.5 & $0.00 \pm 0.00$ & $0.00 \pm 0.00$ & $7.00 \pm 0.00$ & $7.00 \pm 0.00$ & $0.00 \pm 0.00$ \\
\hline & $\begin{array}{l}C: F: W \\
(10: 1: 1)\end{array}$ & 25.0 & $0.00 \pm 0.00$ & $0.00 \pm 0.00$ & $8.00 \pm 0.00$ & $11.00 \pm 0.00$ & $9.33 \pm 0.58$ \\
\hline \multirow[t]{2}{*}{ G } & Unresolved & 12.5 & $0.00 \pm 0.00$ & $0.00 \pm 0.00$ & $0.00 \pm 0.00$ & $0.00 \pm 0.00$ & $0.00 \pm 0.00$ \\
\hline & $\begin{array}{l}C: F: W \\
(10: 1: 1)\end{array}$ & 25.0 & $0.00 \pm 0.00$ & $0.00 \pm 0.00$ & $7.00 \pm 0.00$ & $8.00 \pm 0.00$ & $0.00 \pm 0.00$ \\
\hline
\end{tabular}

Key: KI- Klebsiella pneumoniae, Ps- Pseudomonas aeruginosa, St-Staphylococcus aureus, Sr-Streptococcus pyogenes, Cn-Candida albicans, SEM = Standard error of the mean, CFW: chloroform:formic acid:water $\mathrm{C}: \mathrm{M}=$ chloroform: methanol

\section{DISCUSSION}

Phytochemical screening of the n-butanol fractions revealed the presence of cardiac glycosides, terpenoids, saponins, tannins, anthraquinones, and flavonoids. These classes of secondary metabolites such as alkaloids, saponins, tannins, anthraquinones, and flavonoids were reported to have curative activity against several pathogens and therefore could suggest the use of the plant traditionally for the treatment of various infections (Hassan et al., 2004; Usman and Osuji, 2007; Usman et al., 2009c). Fractions $\mathrm{A}$ and $\mathrm{B}$ showed no inhibition against Klebsiella pneumoniae, Pseudomonas aeruginosa,
Staphylococcus aureus, Streptococcus pyogenes and Candida albicans at a concentration of $25 \mathrm{mg} / \mathrm{ml}$ and $12.5 \mathrm{mg} / \mathrm{ml}$. Fraction $\mathrm{C}$ showed high activities against Klebsiella pneumoniae, Staphylococcus aureus, Streptococcus pyogenes and Candida albicans at concentration of $50 \mathrm{mg} / \mathrm{ml}$ with diameter of inhibition zones (DIZs) of $11.30 \pm 0.0 .58,13.00 \pm 0.00$, $14.33 \pm 0.57$ and $14.00 \pm 0.00$ respectively, while at a concentration of $25 \mathrm{mg} / \mathrm{ml}$, Klebsiella pneumoniae, Staphylococcus aureus, Streptococcus pyogenes and Candida albicans showed activities with DIZs of $12.00 \pm 0.00,13.00 \pm 1.00, \quad 15.00 \pm 1.00$ and $13.00 \pm 0.00 \mathrm{~mm}$ respectively. 
Fraction D showed high activities against Klebsiella pneumoniae, Staphylococcus aureus, Streptococcus pyogenes and Candida albicans with DIZs of $14.00 \pm 1.00,13.00 \pm 0.00,15.33 \pm 0.57$ and $14.00 \pm 0.57 \mathrm{~mm}$ at a concentration of $50 \mathrm{mg} / \mathrm{ml}$ respectively, while at a concentration of $12.5 \mathrm{mg} / \mathrm{ml}$ Klebsiella pneumoniae, Staphylococcus aureus, Streptococcus pyogenes and Candida albicans showed activities with DIZs of $10.00 \pm 0.00,10.33 \pm 0.57$, $12.33 \pm 0.58$ and $10.66 \pm 0.58 \mathrm{~mm}$ respectively. Fraction $\mathrm{E}$ showed activities against Klebsiella pneumoniae, Staphylococcus aureus, Streptococcus pyogenes and Candida albicans with DIZs of $10.00 \pm 0.00, \quad 14.33 \pm 0.58, \quad 15.33 \pm 0.58 \quad$ and $14.66 \pm 0.58 \mathrm{~mm}$ respectively, at a concentration of 50 $\mathrm{mg} / \mathrm{ml}$. Fractions $\mathrm{F}$ and $\mathrm{G}$ showed no inhibition against Klebsiella pneumoniae and Pseudomonas aeruginosa, but slight activities were shown against Staphylococcus aureus, Streptococcus pyogenes and Candida albicans at a concentration of $25 \mathrm{mg} / \mathrm{ml}$ and $12.5 \mathrm{mg} / \mathrm{ml}$. The column fraction $\mathrm{E}$ showed the highest inhibition zones with broader concentrationdependent pattern and so the choice for further evaluation.

This is a bioassay guided study, and as a result, a number of microorganisms used from the previous study (Abubakar et al., 2016; 2017), including four Gram positive organisms: Bacillus subtilis, Staphylococcus aureus, Corynaebacterium species, Streptococcus pyogenes and five Gram negative organisms: Klebsiella pneumoniae, Escherichia coli, Pseudomonas aeruginosa, Salmonella typhi and Shigella dysenteriae, some fungal species Aspergillus flavus and Candida albicans were eliminated due to

\section{REFERENCES}

Abubakar, H.M.G., Karumi, Y., Usman, H. and Tijjani, M. A. (2016).Comparative Phytochemical and Antimicrobial Evaluation of the Aqueous and Methanol Stem Bark Extracts of Diospyros mespiliformis Hochst. ex. A. DC. Sahel J. Vet. Sci. 15(2): 117-121.

Abubakar, H.M.G., Karumi Y. and Usman, H. (2017). Assessment of Microbially Active Phytochemicals from the Partitioned Portions of the Stem Bark Extract of Diospyros mespiliformis Hochst. ex. A. DC. Nigerian Journal of Pharmaceutical Sciences.....in press $A B \cup$ Zaria

Abo, K.A, Ogundele, V. O. and Ashidi, J. S. (1999). Antimicrobial Potentials of Spondias mombin, Croton Zambesicus and Zygoltritonia Crocea. Journal of Pharmacology Research. 5(13): 494-497.

Adams, A. (1966). Composition chimique de quel ques herbs. Mauritanniennes Pour Dromadaires. Journal of Agriculture, Tropical Botany and Application. 13: 225-230.

Adewumi, G.O., Agbedahunsa, J.M., Adebayo, A.C., Aladesanmi, A.J., Murphy, J. and Wando, J. (2001). Screening of Nigerian medicinal plants for Trypanocidal Properties. Journal of Ethnopharmacology. 77:19-24. the poor zones of inhibition they portrayed or lost of activity (El-Mahmood, 2009). Synergism based on the phytoconstituents in the most active fraction might play a major role in extracts that were active from crude and lost activity after partitioning (Abubakar et al., 2016; Mosoko and Eloff, 2005). The n-butanol column fraction $E$ which is the most active base on wide concentration-dependent differences contained cardiac glycosides, tannins, terpenoids, saponins, and free anthraquinones. Many phytomedicines exert their beneficial effects through the addictive or synergistic action of several chemical compounds acting at single or multiple target sites associated with a physiological process, as pointed out earlier by some researchers (Tyler, 1999; Nweze et al., 2004). However, this results shows that the effect is dosedependent and increase in concentration increases the antimicrobial effect. The findings from the study revealed that the column fraction $E$ which is selected based on the significant $((P<0.05)$ level of inhibition between concentrations contained bio-active phytochemicals that can effectively be used to source novel antibiotics.

\section{CONCLUSION}

It is evident that the column chromatographic fraction E (0.76) posses significant antimicrobial properties, we therefore suggest the isolation and possible characterization of the active phytochemical(s).

\section{Acknowledgements}

The authors wish to acknowledge the technical efforts of Mr. Fine Akawo of Chemistry Department and Alhaji Isa Adamu Gulani of Department of Veterinary Medicine, University of Maiduguri.

Bodzogen, B. U., Essen, D., Whitener, C., Browne, F. A. and Applebaum, P. C. (2003). Antibacterial Susceptibility of a Vancomycin Resistant Staphylococcus aureus Strain. Journal of Antimicrobial Chemotherapy.52(5): 864-868.

Burkill, H.M. (1985). The Useful Plants of West Tropical Africa. $2^{\text {nd }}$ edition. Volume 2. Royal Botanical Gardens, Kew, Richmond, United Kingdom p. 636.

El-Mahmood, M.A. (2009). Efficacy of Crude Extracts of Garlic (Allium sativa Linn.) against Nonsomial Escherichia coli, Staphylococcus aureus, Streptococcus pyogenes and Pseudomonas aeruginosa. Journal of Medicinal Plants Research. 3(4): 179-185.

Evans, W.C. (2002). Pharmacognosy. 15th Ed. Saunders Publishers, London. pp. 42-44, 221-229, 246-249, 304-306, 331-332, 391393.

Hassan M.M., Oyewale, A.O., Amupitan, J.O., Abduallahi, M.S. and Okonkwo, E.M. (2004). Preliminary Phytochemical and antibacterial investigation of crude extracts of the root bark of Detarium microcarpum. Journal of Chemical Society of Nigeria. 29: 26-29. 
Kirby, W. M. M., Bauer, A. W., Sherris, J. C. and Turck, M. (1966). Antibiotic Susceptibility Testing by a Standardized Single Disk Method. American Journal of Clinical Pathology. 45: 493-496.

Li, J. and Frances, M. (2009). Commercial Production of Tannins from Radiate Pine Bark for Wood Adhesives. Ipenz Publications. 25(1): 1216.

Liu, A.G., Volker, S. E. Jeffery, E. H. and Erdman, J. W. (2009). Feeding Tomateo and Broccoli Powder Enriched With Bioactive Improves Bioactivity Markers in Rats. Journal of Agriculture. and Food Chemistry. 1: 22-28.

Maundu, P. and Tengnas, B. (2005). Useful Trees and Shrubs for Kenya. World Agroforestry Centre-East and Central Africa Regional Programme, Technical Handbook.35. Nairobi, Kenya. p. 484

Mosoko, P. and Eloff, J.N. (2005). The Diversity of Compounds of Six South African Terminaliacies (Combretaceace) Determined by Bioautography. African Journal Biotechnology. (4): 1425-1431.

Nweze, E. L., Okafor, J. L. and Njoku, O. (2004). Antimicrobial Activities of Methanolic Extracts of Trume guineesis (Schumn. Thorn) and Moringer lucinda used in Nigerian Herbal Medicinal Practice. Journal of Biological Research and Biotechnology. 2(1): 34-46.

Ochiai, K., Yamanaka, T. and Sawada, O. (1959). Inheritance of Drug Resistance and its Transfer between Shigella and E. coli Strains . Hihon Iji Shimpor. 34: 1861.

Simons, A., Orwa, C., Mutua, A., Kindt, R. and Jamnadass, R. (2009). Agroforestry Database: A Tree Reference and Section Guide. Version 4 (internet) Word Agroforestry Centre, Nairobi, Kenya. pp. 102110.

Sofowora, A. (1993). Screening Plants for Bioactive Agents. In: Medicinal Plants and Traditional Medicinal in Africa. 2nd Ed. Spectrum Books Ltd, Sunshine House, Ibadan, Nigeria, pp. 134-156.
Tyler, V.E. (1999). Phytomedicine: Back to Future. Journal of Natural Products.62: 1589-1592.

Usman, H. and Osuji, J.C. (2007). Phytochemical and in vitro anti microbial assay of the leaf extract of Newbouldia leavis. African Journal of Traditional Complementary and Alternative Medicines. 4(4): 476-480.

Usman, H., Abdulrahman, F.I., Kaita, H.A. and Khan, I.Z. (2009a) Antibacterial Assays of the Solvents Partitioned Portions of Methanol Stem bark Extract of Bauhinia rufescens Lam [Leguminosae-Caesalpinioideae]. Pacific Journal Science and Technology. 10(2): 857-867.

Usman, H., Abdulrahman, F.I., Kaita, H.A. and Khan, I.Z. (2009b) Chemical Constituents and In vitro Antibacterial Effects of the Partitioned Portions of Bauhinia rufescens Lam Stem Bark Extract. African Journal of Biomedical Research. 12(3):209-217.

Usman, H., Abdulrahman, F.I. and Usman, A. (2009c). Qualitative Phytochemical Screening and In vitro Antimicrobial Effects of Methanol Stem bark Extract of Ficus thonningii (Moraceae). African Journal of Traditional Complementary and Alternative Medicines. 6(3): 289-295.

Usman, H., Ahmed, I. A., Jidda, A. M. and Tanko, I. (2013a). Comparative Phytochemical and Antimicrobial Efficacy of Combretum glutinosum and Diospyros mespiliformis Leaf Extracts. International Conference Proceeding. $36^{\text {th }}$ Chemical Society Nigeria. Held at Justice Legbo Kutigi Intern. Conf. Centre. Minna, Niger State. Nigeria. pp. 8791.

Usman, H., Abdulrahman, F.I., Ahmed, I.A., Kaita, A.H. and Khan, I.Z. (2013b). Antibacterial Effects of Cyanogenic Glucoside Isolated from the Stem bark of Bauhinia rufescens Lam. International Journal of Biological and Chemical Sciences. 7(5): 2139-2150.

Vishnoi, N.R. (1979). Advanced Practical Chemistry. Yikas Publication House, PVT Ltd., Ghaziabad-India. pp. 447-449. 